розробленні діагностувальних методик визначення рівня інтелектуальної культури.

\title{
Література
}

1. Гриньова В. М. Формування педагогічної культури майбутнього вчителя (теоретичний та методичний аспект) / В. М. Гриньова. - Х. : Основа, 1999. - 300 с. 2. Елканов С. Б. Основы профессионального самовоспитания будущего учителя / Самсадин Бутохович Елканов. - М. : Просвещение, 1989. - 175 с. З. Иванова Т. В. Культурологическая подготовка будущего учителя : [монография]/ Татьяна Викторовна Иванова. - К. : ЦВП, 2005. - 282 с. 4. Пальшкова І. О. Практикоорієнтований підхід у формуванні професійно-педагогічної культури вчителів початкової школи : [монографія] / Ірина Олександрівна Пальшкова. - Одеса : Букаєв Вадим Вікторович, 2009. - 339 с. 5. Семиченко В. А. Пути повышения эффективности изучения психологии / Валентина Анатолиивна Семиченко. - К. : Магістр-в, 1997. - 124 с.

\section{ІМЕРСІЙНА ОСВІТА В КАНАДІ ЯК ЕФЕКТИВНИЙ ЗАСІБ ВИВЧЕННЯ ДРУГОЇ МОВИ}

Устименко В. В. Імерсійна освіта в Канаді як ефективний засіб вивчення другої мови.

У статті розглядається досвід використання французьких імерсійних програм в освіті Канади, розкриваються характерні особливості такого виду навчання, зважаючи на потреби сучасного канадського суспільства. Особлива увага звертається на ефективність імерсійної освіти під час засвоєння другої мови.

Ключові слова: Канада, імерсійна освіта, імерсійні програми, мультилінгвізм.

Устименко В. В. Иммерсионное образование в Канаде как эффективный способ изучения второго языка.

В статье рассматривается опыт использования французских иммерсионных программ в образовании Канады, раскрываются характерные особенности такого вида обучения, учитывая потребности современного канадского общества. Особое внимание уделяется эффективности иммерсионного образования при освоении второго языка.

Ключевые слова: Канада, иммерсионное образование, иммерсионные программы, мультилингвизм.

Ustimenko V. V. Immersion education in Canada as an effective method of learning second language.

The article examines the experience of using French immersion programs in education of Canada, characteristics of such type of training are shown taking into consideration the requirements of modern Canadian society. The special attention is paid to the effectiveness of immersion education while learning second language.

Key words: Canada, immersion education, immersion programs, multilingualism.

В останні десятиліття проблема підготовки людей до життя в багатонаціональному суспільстві в умовах багатомовності та полікультурності перебуває в центрі уваги педагогічних досліджень. Як відомо, мета і зміст будь-якої 
освіти зумовлені, передовсім потребами суспільства. Сучасна Канада розмаїта i багатогранна, наявність мультилінгвізму, співіснування на єдиному просторі великої кількості мов як атрибутів національних культур є закономірним явищем. 25\% канадців у віці від 18 до 29 років володіють обома офіційними мова. Це найбільш високий показник білінгвізму серед людей цього віку у всьому світі.

Проблеми імерсійної освіти в Канаді досліджують О. Андре, Д. Куммінс, Ш. Лепкін, М. Свейн. Індивідуальними виявами учнів, які навчаються за імерсійними програмами, опікуються Г. Карін, Г. Соня, Г. Фред. 3-поміж вітчизняних науковців проблеми імерсійної освіти вивчають О. Першукова, А. Штифурак, І. Міщинська.

Mema cmammi - 3'ясувати причини виникнення імерсійних програм у Канаді, їх ефективність щодо засвоєння другої мови; узагальнити характерні особливості імерсійної освіти в Канаді.

Основною особливістю канадської моделі двомовного навчання $є$ імерсійні програми. Імерсія - це така організація навчального процесу, коли навчання повністю проводиться нерідною для учнів мовою. Імерсійні програми пропонують тривале занурення учнів в іншомовне середовище при винятковому або незначному використанні рідної мови. Деякі науковці розглядають поняття імерсії як ідентичне білінгвальному навчанню [1].

Дослідниця I. Міщинська зазначає, що нещодавно цей термін набув нового значення у програмах імерсії в мовне середовище місцевих мов, які знаходяться під загрозою зникнення. Батьки дітей мовної більшості, які розмовляють рідною мовою, що має високий статус (англомовні жителі Онтаріо), добровільно обирають для своїх дітей вивчення програм, викладання яких ведеться мовою меншин. Більшість дітей, які навчаються в таких класах, $є$ представниками мовної більшості 3 однаковою рідною мовою. Викладачі, задіяні в цих програмах, $є$ двомовними, тож діти на початку можуть застосовувати їхню рідну мову. Ці програми спрямовано на вивчення додаткової мови, водночас рідна мова дітей не перебуває під загрозою бути витісненою мовою навчання [2].

У середині XX століття англомовним жителям провінції Квебек стало зрозуміло, що їх економічне виживання буде неможливим без глибокого знання французької мови. Французька є основною мовою у провінції, водночас англомовне населення, хоча й вивчало iii у школі, проте мало приділяло уваги практичному застосуванню, тому рівень володіння нею не давав змоги повноцінно взаємодіяти 3 носіями французької мови. Наприкінці 60-х рр. в інших провінціях Канади стає зрозумілою цінність французької мови з економічної, політичної та соціальної точок зору. Уряд, у свою чергу, утворив Королівську комісію з вивчення білінгвізму та бікультури $\mathrm{i}$ виділив кошти на вивчення імерсійної освіти та ознайомлення широкого загалу 3 результатами набутого досвіду [3].

Нині в Канаді білінгвізм має низку переваг: економічна перевага полягає в тому, що канадці, які розмовляють обома офіційними мовами, заробляють більше, ніж ті, хто говорить лише англійською або лише французькою мовою; важливо й те, що 3 культурної точки зору двомовні канадці отримують можливість повністю брати участь у житті канадського суспільства; науковці також відмітили багато розумових переваг, які надає вивчення другої мови.

Першу спробу розроблення програм занурення зробив У. Ламберт (1965). У.Ламберт i У.Пенфілд взяли на себе відповідальність упровадження нової програми. Їхня французька імерсійна програма повинна була задовольняти такі вимоги: 
- надавати дітям, що беруть участь у програмі, функціональну компетентність як у писемній, так і розмовній формі французької мови;

- підтримувати нормальний рівень розвитку англійської мови;

- гарантувати успіх у навчальних дисциплінах, що відповідають академічній здатності і рівню студентів;

- забезпечити розуміння і схвалення студентами французьких канадців, не принижуючи англійської канадської культури.

Сподівалися, що імерсійні програми сприятимуть покращенню стосунків між англомовними і франкомовними квебекцями i, навіть більше, між канадцями, що розмовляли різними мовами. Тоді групі англомовних батьків з Монреаля вдалося домогтися того, щоб викладання у школах здійснювалося відбуватися французькою мовою, розпочинаючи з першого класу задля більш швидкого досягнення належного рівня мовної компетенції школяряпів у французькій мові. Програма викладалась французькою мовою за допомогою інструкцій та контекстних підказок.

Імерсійна програма У. Ламберта мала на меті як вивчення другої мови, так і задоволення потреб навчального плану студентів. Програма мала великий успіх, оскільки більшість студентів демонструвала високий рівень володіння французькою мовою. Варто зауважити, що успіх програми поширився не тільки на володіння мовами: студенти досягнули значних успіхів з інших предметів навчального плану, не використовуючи свою англомовну компетенцію [7].

Дослідження, які проводилися в Канаді протягом минулих сорока років, показали, що студенти, які вивчали французьку мову за допомогою імерсійних програм, у всіх типах франкомовних тестів перевершили студентів, які вивчали французьку мову через традиційні шкільні програми. Імерсійні студенти, особливо ті, які брали участь у програмах ранньої французької імерсії, впорались 3 тестами 3 читання й аудіювання так само добре, як і студенти - носії французької мови. Однак імерсійні студенти, зазвичай, не демонструють таких високих результатів під час контролю письма та говоріння [6].

У Канаді імерсійними вважаються лише ті програми білінгвального навчання, у яких частка іноземної мови під час викладання суміжних дисциплін складає не менше п’ятдесяти відсотків. Однією з характерних ознак імерсійної освіти є ії інтенсивність та надзвичайно високий рівень умотивованості учнів, що позначається на результатах навчання та їх соціальному становленні. На думку I. Мампорії, основними характеристиками канадських імерсійних програм є такі:

- Предметні знання однаково добре засвоюються обома мовами.

- Імерсія підходить для всіх школярів. При цьому слабкі учні навчаються не в одній групі з сильними, а в окремій. Отже, реалізується особистісний підхід у навчанні, і невстигаючі учні мають можливість отримати додаткові консультації вчителів.

- Під час упровадження імерсійних програм спостерігається підвищення когнітивних здібностей учнів.

- Імерсійні програми розвивають в учнів позитивне ставлення до чужих мов i культур [1].

Науковці Р. Джонсон та М. Свейн виокремлюють вісім характеристик імерсійних програм:

- L2 - мова викладання матеріалу;

- імерсійний навчальний план є паралельним навчальному плану L1;

- існує велика підтримка L1; 
- програма прагне до сукупного білінгвізму;

- дія L2 в основному обмежена класом;

- студенти розпочинають програму з однаковим рівнем володіння L2;

- учителі що викладають, двомовні;

- культура класу - це культура місцевого суспільства L1[4].

Залежно від віку учнів на момент початку навчання, канадські імерсійні програми поділяють на:

- програми раннього занурення: початок білінгвального навчання 3 дошкільного віку або з 1-2-го класу школи;

- програми середнього занурення: білінгвальне навчання починається в 3, 4 або 5 класі школи;

- програми пізнього занурення: початок білінгвального навчання у шостому класі. Занурення відбувається тільки після попереднього вивчення іноземної мови, за імерсійною програмою викладається лише кілька навчальних предметів.

Залежно від кількості навчальних предметів, які вивчаються іноземною мовою, розрізняють:

- програми повного занурення, згідно з якими 3 самого початку навчання всі предмети викладаються іноземною мовою. Починаючи з третього і четвертого року навчання кількість предметів, що викладаються іноземною мовою, поступово скорочується, поступаючись місцем для вчення рідною мовою;

- програми часткового занурення, згідно 3 якими частина предметів викладається іноземною мовою, частина - рідною [5].

Нині французькі імерсійні програми широко використовуються по всій Канаді. Більшість програм була розвинена після батьківського незадоволення традиційними французькими програмами і бажання долучити своїх дітей до білінгвального навчання. Імерсійні програми іншими мовами, окрім французької, також доступні в Канаді, наприклад, українські, німецькі, польські, гебрайські, китайські [5].

Деякі з цих програм відвідують студенти, які належать до етнічної меншості і вивчили англійську мову як першу мову і таким чином вивчають мову своєї етнічної спадщини. Такі програми відвідують також неангломовні студенти, які бажають засвоїти мову більшості, мову соціалізації - англійську. Канадські студенти, які $є$ носіями англійської мови, можуть брати участь в імерсійних програмах задля вивчення іншої мови для лінгвістичного збагачення. Усі ці програми сприяють поширенню білінгвізму.

\section{Література}

1. Мампория И. Ф. Национальные особенности билингвального обучения [Електронний ресурс] / И. Ф. Мампория. - Режим доступу: http://sarrsute.ru/images/ stories/ articlefoto/rio/yazyk/4/mamporiya_i.pdf. - Заголовок 3 екрана. 2. Міщинська І. В. Основні концепції двомовної освіти у сучасному освітньому просторі / І. В. Міщинська // Вісник Національної академії Державної прикордонної служби України. - Вип. 3. - К., 2012. - С. 22-28. 3. Штифурак А. В. Досвід використання імерсійної освіти за кордоном / А. В. Штифурак // Проблеми трудової і професійної підготовки. - Вип. 17. - Слов'янськ, 2012. - С. 35-43. 4. Cummins J. Immersion Education for the Millennium: What We Have Learned from 30 years of Research on Second Language Immersion, Ontario Institute for Studies in Education of the University of Toronto / J. Cummins // Learning through two languages: Research and practice. Second Katoh Gakuen International Symposium on Immersion and Bilingual education. - Katoh Gakuen, 1998. - P. 34-47. 5. Genesee F. Dual language education in 
Canada and the United States/ F. Genesee, K. Lindholm-Leary // Encyclopedia of Language and Education / [J. Cummins, N. Hornberger]. - New York : Springer, 2007. - P. 253-266. 6. French immersion education in Canada [Електронний ресурс]. - Режим доступу: http://www.ccl-cca.ca/pdfs/ LessonsInLearning/May-17-07-French-immersion.pdf. Заголовок $з$ екрана. 7. Laborda J. Bilingual Education in Canada: Description and Evaluation of the Immersion Programme [Електронний ресурс] / J. Laborda. - Режим доступу: http://webs.uvigo.es/ssl/actas1997/06 /GarciaL.pdf 